\title{
Biznesowe aspekty funkcjonowania chińskich klinik poporodowych - analiza socjologiczno-ekonomiczna
}

\begin{abstract}
The tradition of 'sitting the month' derived from China is still a practiced custom to have a postpartum month after childbirth. Traditional rules applicable in a postpartum period were to help women rejuvenate their bodies after childbirth, to restore the balance of the body and ensure its future health. Today's intensive economic development of China along with the increase in Chinese people's savings contributes to creating a special and sophisticated offer for affluent social groups. An example of such an offer are postnatal clinics designed for wealthy Chinese women who want to have their postnatal period in accordance with traditional practices.

The objective of this article is to show the business aspects of Chinese contemporary postnatal clinics and attempt to answer the question on how modern postnatal clinics combine tradition with modernity to make life easier for mothers, and to what extent they are another idea for doing business. The article addresses the major factors of the demographic and economic environment, which may have an impact on the prosperity of society and on the development of the market of postnatal clinics in the
\end{abstract}

1 Joanna Afek, Katedra Sinologii, Wydział Nauk Humanistycznych, Katolicki Uniwersytet Lubelski Jana Pawła II, Polska, afekjoanna@kul.lublin.pl.

2 Dorota Krupa, Katedra Zarządzania Finansami, Wydział Nauk Ekonomicznych i Zarządzania, Uniwersytet Mikołaja Kopernika w Toruniu, Polska, dkrupa@umk.pl. 
region. It also presents the essence of traditional postpartum practices in China. Offers of services to mothers and their children from forty-six clinics from Taipei in Taiwan were also analysed.

It turns out that postnatal clinics are a phenomenon that could occur only within the Asian community. It is a product, which is very well inscribed in the Asian mentality and cannot be transferred to any another, such as, for instance, to the European mentality. Its future is limited to the Asian markets, or, possibly, to countries which have a Chinese diaspora on their territory. Over time, along with the spread of this traditional practice with a modern twist, the number of post-natal clinics can grow, which can translate into lower prices, a worse quality and a narrower range of services offered.

\section{Key words:}

postnatal centers, postpartum, savings, economic development, China, Taiwan

\section{WSTĘP}

Chińczycy byli i są narodem bardzo przywiązanym do tradycji. To, co zostało zapoczątkowane w starożytności i przetrwało kilka tysięcy lat historii, często funkcjonuje w takiej samej bądź trochę zmienionej formie współcześnie i nie jest uważane za przeżytek, ale za dobro przekazane przez przodków, które należy szanować i hołubić. Często jednak wiele tradycyjnych wierzeń i praktyk przyjmuje nowoczesną formę, nastawioną przede wszystkim na zysk. Tak właśnie wygląda sytuacja ze starym obyczajem odbywania miesięcznego połogu po urodzeniu dziecka $^{3}$. W tradycyjnych Chinach matka po porodzie miała obowiązek odbycia połogu, tzw. miesięcznego siedzenia z dzieckiem (zuoyuezi), z którym wiązało się wiele zakazów (Ji, 2008). Była to praktyka bardzo stara, zapoczątkowana w starożytności, opisana już w Księdze rytuałów ${ }^{4}$. Zasady obowiązujące w połogu miały na celu odzyskanie sił przez kobietę, przywrócenie organizmowi równowagi i zapewnienie mu zdrowia w przyszłości (Liu i in., 2006). W czasie tradycyjnego połogu w centrum zainteresowania była kobieta, dziecko schodziło na dalszy plan.

3 Inne przykłady to sztuka fengshui, czy też sztuki walki.

4 Jedna z klasycznych ksiąg chińskich, znana również jako Zapiski o obyczajach, czy też Księga obyczajów, opisująca starożytne ceremonie dworskie oraz obyczaje ludowe; zredagowana ostatecznie w III wieku p.n.e. 
Przykładem adaptacji tradycyjnych nakazów i przesądów dotyczących praktyk połogowych w Chinach na grunt współczesnego społeczeństwa jest coraz powszechniejsze powstawanie specjalistycznych klinik poporodowych. Należy zauważyć, że w ostatnich latach Chiny były w czołówce w regionie w zakresie intensywności rozwoju gospodarczego, co istotnie przekładało się na wzrost oszczędności społeczeństwa i wyodrębnianie się coraz zamożniejszych grup społecznych. Miało to swój wyraz również w budowaniu specjalnej, wyszukanej oferty dla zamożnych chińskich kobiet.

Celem artykułu jest ukazanie biznesowych aspektów funkcjonowania chińskich współczesnych klinik poporodowych oraz próba odpowiedzi na pytanie, na ile współczesne kliniki poporodowe łączą tradycję z nowoczesnością, by ułatwić życie matkom, a na ile są kolejnym pomysłem na zrobienie biznesu.

\section{METODYKA BADAŃ I PRZEBIEG PROCESU BADAWCZEGO}

W ramach realizacji celu zagadnienia w artykule podzielone zostały na trzy główne części. Część pierwsza artykułu dotyczy najważniejszych czynników otoczenia demograficzno-ekonomicznego, które mogą mieć wpływ na zamożność społeczeństwa i rozwój rynku klinik poporodowych w regionie. W kolejnej części przedstawiono istotę tradycyjnych praktyk związanych z połogiem w Chinach. Następnie przybliżono i scharakteryzowano ofertę klinik oraz wskazano na najważniejsze wnioski płynące z przeprowadzonych analiz. Analizie (ze względu na dostępność danych) zostało poddanych czterdzieści sześć klinik poporodowych z Tajpej, stolicy Tajwanu.

\section{OTOCZENIE DEMOGRAFICZNO-EKONOMICZNE}

W prognozach Międzynarodowego Funduszu Walutowego zawartych w raporcie z 2013 roku (International Monetary Fund, 2013) dotyczących realnego PKB w 2018 roku rozwijające się państwa Azji mają osiągnąć roczny wzrost rzędu 7,7\% (Chiny 8,5\%), co jest znacznie wyższym poziomem w porównaniu z resztą światowych systemów gospodarczych (np. USA 2,5\%, UE 2,9\%, Japonia 1,1\% wzrostu PKB w 2018 roku). Przewidywania co do poziomu oszczędności i inwestycji wyrażonych jako średnia udziału w PKB w latach 2015-2018 także są znacznie wyższe dla rozwijających się azjatyckich systemów gospodarczych (wynoszą dla oszczędności 44,5\% PKB, a dla inwestycji 42,5\% PKB) w porów- 
naniu ze Stanami Zjednoczonymi (odpowiednio 16,4\% PKB i 19,7\% PKB) czy obszarem euro (oszczędności to 21,2\% PKB, inwestycje 18,5\% PKB). Obecnie w Azji jest wiele rozwijających się systemów gospodarczych. Na wykresie 1 zaprezentowano tempo wzrostu realnego PKB w 2012 roku oraz prognozy na lata 2013, 2014 oraz na rok 2018 dla Chin, które zaliczane są do czołówki rozwijających się państw azjatyckich. Na wykresie osobno wyodrębniono Tajwan ze względu na fakt, iż zaliczany jest on do państw rozwiniętych. Przewiduje się, że Tajwan osiągnie najwyższych wzrost PKB w roku 2018 w grupie rozwiniętych krajów azjatyckich.

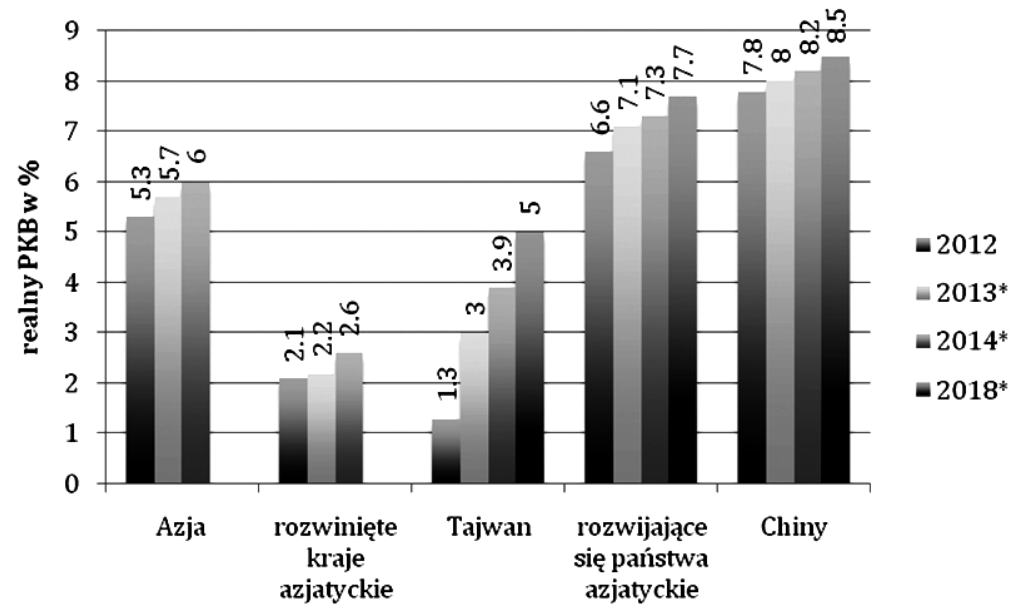

Wykres 1. Realny PKB w Azji w okresie 2012-2018

*prognozy MFW

Źródło: Opracowanie własne na podstawie International Monetary Fund (2013). World economic outlook: hopes, realities, risk. World Economic and Financial Surveys. Pobrane z: http://www.imf.org/external/pubs/ft/weo/2013/01/pdf/text.pdf, s. 56, 168, 171.

Należy zauważyć, że mimo intensywnego rozwoju gospodarczego, region Azji zmagać się będzie z konsekwencjami ekonomicznymi zachodzących zmian demograficznych. Ludność Azji stanowi 60\% ogółu ludności świata. Prognozy Organizacji Narodów Zjednoczonych (United Nations, 2009) wskazują na przyrost liczby ludności w tym regionie o ponad 5\% do końca roku 2015 i o 25\% do 2050 roku.

Chiny wśród krajów azjatyckich są w szczególnej sytuacji. Propagowana od ponad 30 lat polityka jednego dziecka, przyczyniając się do znacznego zmniej- 
szenia przyrostu naturalnego, sprawiła, iż rząd chiński stoi przed perspektywą zwiększenia tempa starzenia się społeczeństwa (Westley, Mason, 2002)5 .

Należy jednak zauważyć, że jak wykazują badania Ge, Yang, Zhang (2012) ograniczenie liczby dzieci przełożyło się na wzrost oszczędności gospodarstw domowych w Chinach. Część chińskich gospodarstw domowych, których okres prokreacji przypadał na czas obowiązywania polityki jednego dziecka, posiadając mniejszą liczbę dzieci na utrzymaniu, było w stanie więcej zaoszczędzić w porównaniu do rodzin wielodzietnych. Ponadto kolejne pokolenia takich rodzin (z jednym dzieckiem) mogły liczyć na większe wsparcie finansowe rodziców. Chiny mają więc obecnie do czynienia z sytuacją, w której nie tylko osiągają wysokie tempo wzrostu PKB oraz bardzo wysoki udział oszczędności w PKB, ale jednocześnie oszczędności te stymulowane są ograniczeniem wydatków konsumpcyjnych w gospodarstwach domowych ze względu na posiadanie małej liczby dzieci. Samo minimalne złagodzenie polityki jednego dziecka w 2013 roku dotyczące możliwości posiadania drugiego dziecka, o ile jedno z rodziców jest jedynakiem, nie wydaje się w krótkim okresie istotnie zaburzyć obecny stan, podobnie jak zapowiedziane w 2015 roku zmiany dające możliwość każdej parze posiadania dwójki dzieci.

\section{POŁÓG W CHINACH - TRADYCJA A WSPÓŁCZESNOŚĆ}

Zakazy, które obowiązywały kobietę w połogu w Chinach tradycyjnych, obejmowały przede wszystkim zachowanie, higienę i dietę (Ren, 2005). Kobieta musiała odbywać połóg w spokoju i dostatku, zabronione jej było wychodzenie na dwór, a nawet opuszczanie pokoju, w którym przebywała z dzieckiem. Nie mogła wykonywać żadnych prac domowych (był to jedyny okres w życiu młodej kobiety, kiedy usługiwała jej teściowa). Musiała unikać zimna, przeciągów, zimnej wody. Nie mogła się ani kąpać (ciało wycierała mokrym ręcznikiem), ani myć włosów i zębów. Zabronione były jakiekolwiek kontakty seksualne. Obowiązywała ją ściśle określona dieta, która zapewniała szybką rekonwalescencję i dużą ilość pokarmu, a dziecku zdrowy, prawidłowy rozwój. Dieta ta była uzupełniana lekarstwami tradycyjnej medycyny chińskiej.

5 Zmiany przyjęte w 2013 roku dopuszczają posiadanie przez rodzinę drugiego dziecka, o ile jedno z rodziców jest jedynakiem (http://news.xinhuanet.com/english/china/2013-12/28/c_133002754. htm), z kolei w 2015 roku zapowiedziano zmiany dające możliwość posiadania dwójki dzieci wszystkim parom (http://swiat.newsweek.pl/polityka-jednego-dziecka-w-chinach-zakonczona,artykuly,373096,1.html). 
Sam fenomen „wysiadywania miesiąca” interesował wielu badaczy, nikt natomiast nie badał współczesnych klinik poporodowych (opisywane są jedynie w prasie codziennej). I tak praktykę „wysiadywania miesiąca” przez chińskie emigrantki mieszkające w Szkocji zbadała Cheung (1997). Składały się na nią: pozostawanie w domu, unikanie wszystkiego, co zimne (zimny wiatr, zimna woda, zimne jedzenie), zbilansowana dieta oparta na zasadach yin i yang, zwolnienie z obowiązków domowych, powstrzymanie się od aktywności towarzyskiej. Cheung (1997) opisuje dodatkowo bardzo ciekawy zwyczaj, a mianowicie „wysiadywanie małego miesiąca” (zuoxiaoyuezi), który polega na odbyciu tradycyjnego połogu po dokonaniu aborcji. Niektóre kobiety, uważając, że ich poprzednie „wysiadywanie miesiąca” przebiegło niewłaściwie, specjalnie zachodzą w ciążę i usuwają ją, aby odbyć połóg prawidłowo i w ten sposób zabezpieczyć swoje zdrowie na starość.

Natomiast Liu i in. (2006) przebadali ponad dwa tysiące Chinek w wieku od 18 do 44 lat z prowincji Hubei, które w ostatnich dwóch latach urodziły dziecko i „wysiadywały miesiąc”. Badaczy interesowała przede wszystkim dieta matek oraz to, w jakim stopniu stosowały się do tradycyjnych zakazów. Wiele kobiet podporządkowywało się tradycyjnym zakazom związanym z „wysiadywaniem miesiąca”: 54,9\% kobiet nie wstało z łóżka przez dwa dni po porodzie; 25,2\% kobiet wierzyło, że należy przebywać w domu i chronić się przed wiatrem; 53,7\% zakładało więcej ubrań niż zazwyczaj, aby chronić się przed zimnem; 32,7\% kobiet nie wychodziło na dwór; 80\% nie wykonywało żadnej pracy fizycznej; 62,1\% kobiet wróciło do pożycia seksualnego po 42 dniach, 18,7\% pomiędzy 30 a 42 dniem, 19,1\% przed upływem 30 dni; 24,5\% kobiet nie kąpało się, 32,3\% nie myło włosów, 13,3\% nie myło zębów. Badacze doszli do wniosku, że tradycyjne zakazy i przesądy związane z „wysiadywaniem miesiąca” są nadal przestrzegane, ale w większym stopniu na terenach wiejskich i wśród gorzej wykształconych kobiet. Inne badania dowodzą jednak, że obyczaj ten pozostaje szeroko rozpowszechniony zarówno w samych Chinach i na Tajwanie, jak i poza ich granicami, wśród chińskiej diaspory (Bao i in., 2010).

Zagadnieniem „wysiadywania miesiąca” zajmowali się również Raven i in. (2007), którzy badali Chinki odbywające połóg w chińskiej prowincji Fujian. Badacze doszli do wniosku, że większość zakazów i nakazów obowiązujących w czasie połogu jest pożyteczna z punktu widzenia zachodniej medycyny. Za praktykę szkodliwą dla matki uznano jedynie miesięczny brak higieny jamy ustnej. 


\section{WYNIKI ORAZ WNIOSKI PROCESU BADAWCZEGO - KLINIKI POPORODOWE JAKO PRÓBA ADAPTACJI TRADYCYJNYCH PRAKTYK}

Obecnie wiele kobiet nie ma zapewnionej wspomnianej tradycyjnej opieki teściowej w czasie połogu, dlatego musi szukać innych rozwiązań. Jedną z tańszych opcji jest wynajęcie na ten okres specjalnej (lepiej lub gorzej wykwalifikowanej) opiekunki, zwanej zuoyuezi aiyi lub też yuesao, która mieszka z matką i noworodkiem, opiekując się nimi przez całą dobę (od zwykłej pomocy domowej różni się tym, że jest zatrudniana na miesiąc i do jej obowiązków należy jedynie dbanie o matkę i dziecko). Obecnie można również, za bardzo wysoką opłatą, odbyć połóg w wyspecjalizowanej klinice, oferującej kompleksową opiekę nad matką i dzieckiem, których jest w Chinach kontynentalnych i na Tajwanie, zwłaszcza w dużych miastach, coraz więcej.

Na Tajwanie pierwsze kliniki poporodowe powstały w latach 80. ubiegłego wieku. Natomiast w Chinach kontynentalnych dekadę później (Attané, 2012). Obecnie w dużych miastach otwiera się takich klinik coraz więcej (Pekin ma ich kilka, Szanghaj ponad trzydzieści, Tajpej ponad czterdzieści), a moda ta dociera także do mniejszych miejscowości. W rezultacie w Chinach funkcjonuje około dwustu takich klinik (Wang, 2013). Mimo to do wielu z nich trzeba zapisywać się z dużym wyprzedzeniem. Nie podlegają one pod Ministerstwo Zdrowia, więc nie ma nad nimi żadnej kontroli (rejestrowane są jako usługi biznesowe).

W samym Tajpej, liczącym ok. 2,6 mln mieszkańców, jest czterdzieści sześć klinik poporodowych, które dzielą się na przyszpitalne i niezależne. Te pierwsze znajdują się przy publicznych lub prywatnych szpitalach, drugie otwierane są niezależnie, ale często współpracują z lekarzami z oddziałów położniczych i ginekologicznych oraz pediatrami pracującymi w szpitalach.

Wykaz klinik w Tajpej wraz z podstawowymi charakterystykami zaprezentowano w tabeli 1.

Tabela 1. Kliniki poporodowe w Tajpej, stolicy Tajwanu, stan na listopad 2013 roku

\begin{tabular}{lllll}
\hline Lp. & nazwa kliniki/ adres strony internetowej & $\begin{array}{l}\text { liczba } \\
\text { pokoi }\end{array}$ & $\begin{array}{l}\text { status } \\
\text { stawka } \\
\text { dobowa } \\
\text { w TWD }\end{array}$ \\
\hline 11 & $\begin{array}{l}\text { Cheng Hsin Hospital Postpartum Care Centre } \\
\text { http://home.chgh.org.tw/mababy/index.html }\end{array}$ & 30 & w szpitalu & 7000 \\
\hline 22 & $\begin{array}{l}\text { Taiwan Adventist Hospital Postpartum Care } \\
\text { Centre } \\
\text { brak strony internetowej }\end{array}$ & 20 & w szpitalu & $6000-8000$ \\
\hline
\end{tabular}




\begin{tabular}{|c|c|c|c|c|}
\hline Lp. & nazwa kliniki/ adres strony internetowej & $\begin{array}{l}\text { liczba } \\
\text { pokoi }\end{array}$ & status & $\begin{array}{l}\text { stawka } \\
\text { dobowa } \\
\text { w TWD }\end{array}$ \\
\hline 33 & $\begin{array}{l}\text { Taipei Medical University Hospital Postpartum } \\
\text { Care Centre } \\
\text { http://www.tmuh.org.tw }\end{array}$ & 19 & w szpitalu & $6020-7400$ \\
\hline 54 & $\begin{array}{l}\text { Taipei Citi Hospital Postpartum Care Centre } \\
\text { http://www.tpech.gov.tw/mp.asp?mp=109011 }\end{array}$ & 20 & w szpitalu & $5200-7000$ \\
\hline 55 & $\begin{array}{l}\text { Taipei Citi Hospital Postpartum Care Centre } \\
\text { Brak strony internetowej }\end{array}$ & 35 & w szpitalu & $4350-5200$ \\
\hline 66 & $\begin{array}{l}\text { Taipei City Hospital Postpartum Care Centre } \\
\text { brak strony internetowej }\end{array}$ & 10 & w szpitalu & 5200 \\
\hline 77 & $\begin{array}{l}\text { Dr. Hsu Obsgyn Clinic } \\
\text { http://www.momcare.com.tw }\end{array}$ & 13 & $\begin{array}{l}\text { przy } \\
\text { klinice }\end{array}$ & $4400-7600$ \\
\hline 88 & $\begin{array}{l}\text { Lizz Postpartum Nursin Centre } \\
\text { http://www.lizz.com.tw }\end{array}$ & 14 & niezależna & 6200 \\
\hline 99 & $\begin{array}{l}\text { Yong'an Postpartum Care Centre } \\
\text { http://www.forever30.com.tw }\end{array}$ & 13 & $\begin{array}{l}\text { niezależ- } \\
\text { na* }\end{array}$ & $5200-6600$ \\
\hline 110 & $\begin{array}{l}\text { Yongxin Postpartum Care Centre } \\
\text { www.forever30.com.tw }\end{array}$ & 17 & $\begin{array}{l}\text { niezależ- } \\
\text { na* }\end{array}$ & $5200-6600$ \\
\hline 111 & $\begin{array}{l}\text { Yongjia Postpartum Care Centre } \\
\text { www.forever30.com.tw }\end{array}$ & 17 & $\begin{array}{l}\text { niezależ- } \\
\text { na* }\end{array}$ & $5500-6800$ \\
\hline 112 & $\begin{array}{l}\text { Yong'an Fuhua Postpartum Care Centre } \\
\text { www.forever30.com.tw }\end{array}$ & 40 & niezależna & $6000-7200$ \\
\hline 113 & $\begin{array}{l}\text { Yono Maternal Centre } \\
\text { http://www.yono.com.tw }\end{array}$ & 23 & niezależna & $5200-6380$ \\
\hline 114 & $\begin{array}{l}\text { Manyuan Postpartum Care Centre } \\
\text { http://www.monyan.com }\end{array}$ & 13 & $\begin{array}{l}\text { niezależ- } \\
\text { na* }\end{array}$ & $3800-5800$ \\
\hline 115 & $\begin{array}{l}\text { Komphort Postpartum Care Centre } \\
\text { http://www.komphort.com.tw }\end{array}$ & 9 & $\begin{array}{l}\text { niezależ- } \\
\text { na* }\end{array}$ & $6800-7500$ \\
\hline 116 & $\begin{array}{l}\text { Komphort Postpartum Care Centre } 1988 \\
\text { http://www.komphort.com.tw }\end{array}$ & 27 & $\begin{array}{l}\text { niezależ- } \\
\text { na* }\end{array}$ & $6500-7800$ \\
\hline 117 & $\begin{array}{l}\text { Komphort Postpartum Care Centre } \\
\text { http://www.komphort.com.tw }\end{array}$ & 12 & niezależna & $6900-7900$ \\
\hline 118 & $\begin{array}{l}\text { Komphort Postpartum Care Centre } \\
\text { http://www.komphort.com.tw }\end{array}$ & 11 & niezależna & $6900-7900$ \\
\hline 119 & $\begin{array}{l}\text { Wei Ke Postpartum Care Centre } \\
\text { http://www.we-gogo.com.tw }\end{array}$ & 10 & $\begin{array}{l}\text { niezależ- } \\
\text { na* }\end{array}$ & $5500-7500$ \\
\hline 220 & $\begin{array}{l}\text { Wei Ge Postpartum Care Centre } \\
\text { http://www.we-gogo.com.tw }\end{array}$ & 10 & $\begin{array}{l}\text { niezależ- } \\
\text { na* }\end{array}$ & $5500-7500$ \\
\hline 221 & $\begin{array}{l}\text { Wu Kung Kuang Women Clinic } \\
\text { http://www.wukunkuang.com.tw }\end{array}$ & 11 & $\begin{array}{l}\text { przy } \\
\text { klinice }\end{array}$ & $4800-5800$ \\
\hline
\end{tabular}




\begin{tabular}{|c|c|c|c|c|}
\hline Lp. & nazwa kliniki/ adres strony internetowej & $\begin{array}{l}\text { liczba } \\
\text { pokoi }\end{array}$ & status & $\begin{array}{l}\text { stawka } \\
\text { dobowa } \\
\text { w TWD }\end{array}$ \\
\hline 222 & $\begin{array}{l}\text { Zhou Da Zhong Postpartum Care Centre } \\
\text { http://www.topcare.com.tw }\end{array}$ & 12 & $\begin{array}{l}\text { przy } \\
\text { klinice }\end{array}$ & $5200-5800$ \\
\hline 223 & $\begin{array}{l}\text { Linda’s Mother-Baby Care Home } \\
\text { http://www.fashionlinda.com.tw }\end{array}$ & 20 & niezależna & $5500-8000$ \\
\hline 224 & $\begin{array}{l}\text { Dun Nan True Love Hall Postpartum Care Centre } \\
\text { http://www.true-love.com.tw }\end{array}$ & 12 & niezależna & 7000 \\
\hline 225 & $\begin{array}{l}\text { Dun Nan True Love Postpartum Care Centre } \\
\text { http://www.true-love.com.tw }\end{array}$ & 11 & niezależna & 7000 \\
\hline 226 & $\begin{array}{l}\text { Babymoon Postpartum Care Centre } \\
\text { http://www.babymoon.com.tw }\end{array}$ & 9 & niezależna & $6800-8080$ \\
\hline 227 & $\begin{array}{l}\text { Ma Chérie Post Partum Centre } \\
\text { http://www.ma-cherie.com.tw }\end{array}$ & 20 & $\begin{array}{l}\text { niezależ- } \\
\text { na* }\end{array}$ & $6300-7500$ \\
\hline 228 & $\begin{array}{l}\text { Ma Chérie Post Partum Centre } \\
\text { http://www.ma-cherie.com.tw }\end{array}$ & 13 & $\begin{array}{l}\text { niezależ- } \\
\text { na* }\end{array}$ & $7980-8080$ \\
\hline 229 & $\begin{array}{l}\text { Li Yi Nan Obstetrics Clinic Postpartum Care } \\
\text { Centre } \\
\text { http://leeobs-gyn.com.tw }\end{array}$ & 15 & $\begin{array}{l}\text { niezależ- } \\
\text { na* }\end{array}$ & $4200-5000$ \\
\hline 330 & $\begin{array}{l}\text { Xie He Women Hospital Postpartum Care Centre } \\
\text { http://www.woman.org.tw }\end{array}$ & 35 & $\begin{array}{l}\text { przy } \\
\text { szpitalu }\end{array}$ & $5200-7000$ \\
\hline 331 & $\begin{array}{l}\text { Lantan Mum’s Care } \\
\text { http://www.lantan101.com }\end{array}$ & 15 & niezależna & $6800-7600$ \\
\hline 332 & $\begin{array}{l}\text { Lantan Mum’s Care } \\
\text { http://www.lantan101.com }\end{array}$ & 9 & niezależna & $6500-7500$ \\
\hline 333 & $\begin{array}{l}\text { XinYue Postpartum Care Centre } \\
\text { http://www.cenya.com.tw }\end{array}$ & 15 & niezależna & $5200-6500$ \\
\hline 334 & $\begin{array}{l}\text { Xi Duo Postpartum Care Centre } \\
\text { http://www.happyhito.com.tw }\end{array}$ & 9 & $\begin{array}{l}\text { niezależ- } \\
\text { na* }\end{array}$ & $4500-6500$ \\
\hline 335 & $\begin{array}{l}\text { Chiching Postpartum Care } \\
\text { http://www.mommycare.com.tw }\end{array}$ & 20 & niezależna & 8080 \\
\hline 336 & $\begin{array}{l}\text { U Sweet Postpartum Care } \\
\text { http://www.usweet.com.tw }\end{array}$ & 14 & niezależna & 7000 \\
\hline 337 & $\begin{array}{l}\text { Your Baby Postpartum Centre } \\
\text { http://www.yourbaby.tw }\end{array}$ & 12 & $\begin{array}{l}\text { niezależ- } \\
\text { na* }\end{array}$ & $6500-7000$ \\
\hline 338 & $\begin{array}{l}\text { Elgar Postpartum Care } \\
\text { http://www.elgarppc.com.tw }\end{array}$ & 22 & niezależna & $6600-7600$ \\
\hline 339 & $\begin{array}{l}\text { CHM Postpartum Nursery Home } \\
\text { http://www.cathay-hcm.com.tw }\end{array}$ & 20 & niezależna & $6700-8000$ \\
\hline 440 & $\begin{array}{l}\text { Fruitful } \\
\text { http://fruitful.com.tw }\end{array}$ & 15 & niezależna & 6200 \\
\hline
\end{tabular}




\begin{tabular}{lllll}
\hline Lp. & nazwa kliniki/ adres strony internetowej & $\begin{array}{l}\text { liczba } \\
\text { pokoi }\end{array}$ & status & $\begin{array}{c}\text { stawka } \\
\text { dobowa } \\
\text { w TWD }\end{array}$ \\
\hline 441 & $\begin{array}{l}\text { Infant Joy } \\
\text { http://www.infantjoy.com.tw }\end{array}$ & b.d. & niezależna & $7000-8000$ \\
\hline 442 & $\begin{array}{l}\text { Taipei City Hospital } \\
\text { http://www.tpech.gov.tw }\end{array}$ & 20 & $\begin{array}{l}\text { przy } \\
\text { szpitalu }\end{array}$ & 5600 \\
\hline 443 & $\begin{array}{l}\text { Wei En Postpartum Care Centre } \\
\text { http://www.we-gogo.com.tw }\end{array}$ & 24 & niezależna & $5050-7500$ \\
\hline 444 & $\begin{array}{l}\text { Celeborn Postpartum Holidays } \\
\text { http://www.celeborn.com.tw }\end{array}$ & b.d. & niezależna & $7860-8080$ \\
\hline 445 & $\begin{array}{l}\text { Youthwell } \\
\text { http://www.youthwell.com.tw }\end{array}$ & b.d. & niezależna & $6880-8080$ \\
\hline 446 & $\begin{array}{l}\text { Wen Hua Yuan Postpartum Care Centre } \\
\text { http://www.wenhua-garden.com }\end{array}$ & b.d. & niezależna & $6800-8080$ \\
\hline
\end{tabular}

*oznaczono współpracę ze szpitalem

Źródło: Opracowanie własne na podstawie http://www.healthcity.net.tw/care_house/.

Najstarsze z zaprezentowanych w tabeli 1 klinik rozpoczęły działalność już w latach 80., np. Xie He Women Hospital Postpartum Care Centre w roku 1987. Rozwój tego rodzaju działalności jest bardzo dynamiczny, wiele z nich (często funkcjonujących pod tą samą nazwą, jak np. Komphort Postpartum Care Centre) to kolejne filie tej samej kliniki. Większość klinik posiada strony internetowe, ale tylko w języku chińskim, co jest zrozumiałe, gdyż kierują one swoje usługi do Chinek. Kliniki te są przeznaczone również dla klientek bardzo zamożnych - ceny za ich usługi są bardzo wysokie, wahają się od 3800 TWD do 8080 TWD za dobę, czyli od ok. 400 PLN do 850 PLN . Należy zaznaczyć, że w Chinach kontynentalnych usługi te są jeszcze droższe - np. sieć Care Bay Maternity Services, założona w 2007 roku, z dwiema klinikami w Szanghaju i jedną w Pekinie, pobiera od 70 000 CNY do 580000 CNY za miesiąc, czyli od ok. 35500 PLN do 300000 PLN (Wang, 2013). Jest to usługa skierowana do najzamożniejszych obywateli, ale tak jak w przypadku Tajwanu można zakładać, że wraz ze wzrostem liczby tych klinik ceny będą spadać.

W większości kliniki przypominają wysokiej klasy hotele z luksusowymi pokojami lub apartamentami, w których mieszkają matki, natomiast dzieci przebywają razem w osobnej sali, przynoszone są matkom na karmienie lub gdy ta wyrazi taką

6 Przelicznik wg http://www.bankier.pl/inwestowanie/waluty/narzedzia/kalkulator_walutowy /?gclid=CMemz6faibsCFcVX3godFDEAlw. 
ochotę. Liczba pokoi waha się od kilku do kilkudziesięciu. Miejsc dla dzieci jest zawsze więcej (na wypadek bliźniąt lub większej liczby niemowląt). W klinikach znajduje się również izolatka, gdzie przebywają dzieci chore (dopóki nie zostaną przewiezione do szpitala). Pokoje dla matek mają bardzo wysoki standard - wyposażone są w telewizor LCD, odtwarzacz DVD, telefon, bezprzewodowy dostęp do Internetu, lodówkę, kuchenkę mikrofalową, klimatyzację, prasę codzienną, czasopisma i książki itp. W większości klinik w pokojach znajduje się specjalny fotel przystosowany do karmienia dziecka, poduszka poporodowa zapobiegająca hemoroidom, laktator, sterylizator oraz inne niezbędne utensylia przydatne w opiece nad niemowlęciem. Temperatura w pomieszczeniach jest dosyć wysoka - ok. 25 stopni Celsjusza. Kobiety mają łazienki, z których mogą dowolnie korzystać (mogą brać prysznic, kąpać się, myć włosy - wedle uznania). Pokoje dezynfekuje się raz w tygodniu. Dzieci są stale monitorowane - matka oraz rodzina może przez Internet przez dwadzieścia cztery godziny na dobę oglądać dziecko. Położnice objęte są różnymi programami edukacyjnymi prowadzonymi przez specjalistów, uczone są jak prawidłowo karmić i pielęgnować dziecko (przewijać, kąpać, ubierać). Mogą brać również udział w różnych dodatkowych zajęciach, w tym gimnastycznych (takich jak pilates, joga), które mają im pomóc w powrocie do sylwetki sprzed ciąży. Mają zapewnione od pięciu do siedmiu posiłków dziennie, które są oczywiście odpowiednio skomponowane przez dietetyków i kucharzy, a przygotowywane są z najwyższej jakości produktów. Jak widać współczesny połóg różni się w wielu kwestiach od tego tradycyjnego - co prawda kobiety przebywają w zamknięciu miesiąc, nie wykonują żadnych prac (ani domowych, ani przy dziecku), są na specjalnej diecie, ale mogą się kąpać, gimnastykować, mogą być odwiedzane przez rodzinę i znajomych. To, co najbardziej różni nowoczesny połóg od tradycyjnego, to podejście do dziecka?

W czasie tradycyjnego połogu w centrum zainteresowania była kobieta, dziecko schodziło na dalszy plan. Obecnie nowoczesne kliniki zapewniają nie tylko profesjonalną opieką kobiecie, ale również dziecku, dbając o jego prawidłowy i szczęśliwy rozwój już od pierwszych dni po urodzeniu. Niemowlęta przebywają w klimatyzowanych salach, w antybakteryjnych i antyalergicznych łóżeczkach, pod stałą opieką pielęgniarek i pod kontrolą pediatrów, są codziennie ważone i mierzone, odpowiednio masowane, w niektórych klinikach kąpane w specjalnych basenach. W wielu klinikach pokazywane są im specjalne czarno-białe karty sty-

7 Zmiana tego podejścia przejawia się na wiele sposobów: zapobiegawczy rodzice często planują narodziny potomka, tak aby miał odpowiedni szczęśliwy znak zodiaku, a także właściwą (zapewniającą pomyślność i bogactwo) datę i godzinę przyjścia na świat (stąd bardzo wysoki odsetek operacji cesarskiego cięcia w Chinach i na Tajwanie), jak również odpowiednie, wybrane przez wróżbitę, imię. 
mulacyjne, puszczana odpowiednia muzyka (tak, aby rozwijać IQ oraz EQ każdego dziecka). Opiekują się nimi pielęgniarki, przynajmniej dwa razy w tygodniu bada pediatra, w razie jakichkolwiek komplikacji przewożone są do szpitala.

Kliniki poporodowe na Tajwanie i w Chinach nadają starej tradycji nowoczesną formę. Są odpowiedzią na zmiany demograficzne i mentalne, a także wzrost zamożności społeczeństwa chińskiego. Oferowane przez nie warunki są na bardzo wysokim poziomie i skierowane są do zamożniejszej części społeczeństwa - powstają w dużych, bogatych aglomeracjach. Jest to produkt, który bardzo dobrze wpisał się w mentalność azjatycką, nie może być przeniesiony na inny, np. europejski grunt. Jego przyszłość ogranicza się do rynków azjatyckich, ewentualnie krajów, gdzie mieszka duża diaspora chińska. W Nowym Yorku w USA działają już cztery takie kliniki (Lee, 2011). Z biegiem czasu, wraz z upowszechnieniem się tej tradycyjnej praktyki w nowoczesnym wydaniu, liczba klinik poporodowych może wrosnąć, co w rezultacie może przełożyć się na spadek cen oraz jakości czy zakresu proponowanych usług.

Rozwojowi tego rodzaju działalności sprzyjać może, z jednej strony, silne przywiązanie do tradycyjnych praktyk, z drugiej szybki rozwój gospodarczy i rosnąca zamożność społeczeństwa chińskiego. Polityka jednego dziecka propagowana od końca lat 70. ubiegłego wieku przez rząd chiński, która, opierając się na zasadach eugeniki, wzmaga nieetyczne zachowania w społeczeństwie, również może przyczyniać się do zwiększenia zakresu „celebracji” okresu poporodowego.Wpływać może m.in. na wzrost skłonności do finansowania pobytu położnic w klinikach poporodowych, niejednokrotnie bardzo luksusowych, tym bardziej że ograniczenie liczby dzieci przełożyło się na wzrost oszczędności gospodarstw domowych w Chinach. Próby łagodzenia polityki jednego dziecka, podjęte w 2013 roku, a następnie zapowiadane w 2015 roku zmiany wprowadzające politykę dwójki dzieci, nie wydają się istotnie przyczynić do wzrostu narodzin w najbliższych latach.

Prezentowany temat z pewnością wymaga dalszych badań i analiz, które mogłyby koncentrować się na identyfikacji segmentów klientek klinik poporodowych zarówno w aspekcie ekonomicznym, jak i socjologicznym, a także na działalności samych klinik. Zbadanie zyskowności tego rodzaju działalności w obliczu szybszego niż w innych częściach świata rozwoju gospodarczego państw azjatyckich dałoby z pewnością szerszy obraz adaptacji starych, tradycyjnych praktyk do wymogów współczesnego rynku. 


\section{Literatura:}

Attané, I. (2012). Tam gdzie dzieci są luksusem. Chiny wobec katastrofy demograficznej. Warszawa: Wydawnictwo Studio Emka.

Bao, Wei, Ma, Aiguo i in. (2010). Diet and Lifestyle Interventions in Postpartum Women in China: Study Design and Rationale of a Multicenter Randomized Controlled Trial. BMC Public Health, 103 (10). Pobrane z: http://www.biomedcentral.com/14712458/10/103. DOI: http://dx.doi.org/10.1186/1471-2458-10-103.

Cheung, N.F. (1997). Chinese zuoyuezi (Sitting in for the First Month of the Postnatal Period in Scotland). Midwifery, 13, s. 55-65. DOI: http://dx.doi.org/10.1016/S02666138(97)90057-7.

Ge, S., Yang, D.T., Zhang, J. (2012). Population Policies, Demographic Structural Changes, and the Chinese Household Saving Puzzle. IZA Discussion Paper 7026. Pobrane z: http://ssrn.com/abstract=2186804.

International Monetary Fund (2013). World economic outlook: hopes, realities, risk. World Economic and Financial Surveys. Pobrane z: http://www.imf.org/external/pubs/ft/ weo/2013/01/pdf/text.pdf.

Ji, Wei. (2008). Tujie Zhongguo guosu (Obrazowe objaśnienie chińskich zwyczajów narodowych). Xi'an: Shanxi shi Fandaxue chubanshe.

Lee, P.F. (2011). In Queens, New Mothers and an Old Asian Custom. The New York Times, June 3. Pobrane z: http://www.nytimes.com/2011/06/05/nyregion/bringing-an-asiantradition-for-new-mothers-to-new-york.html?pagewanted=all\&_r=0.

Liu, Nian, Mao, Limei i in. (2006). Postpartum Practices of Puerperal Women and their Influencing Factors in Three Regions of Hubei. China. BMC Public Health, 274 (6). Pobrane z: http://www.biomedcentral.com/1471-2458/6/274.

Raven, J.H., Chen Qiyan, Tolhurst R.J., Garner P. (2007). Traditional Beliefs and Practices in the Postpartum Period in Fujian Province. China: a Qualitative Study. BMC Pregnancy and Childbirth, 8 (7). DOI: http://dx.doi.org/10.1186/1471-2393-7-8.

Ren, Cheng. (2005). Zhongguo minzu tongzhi. Jinjizhi (Zbiór zwyczajów chińskich. Zbiór zakazów). Jinnan: Shandong jiaoyu chubanshe.

Sanjuan, Th. (2009). Leksykon wiedzy o Chinach współczesnych. Warszawa: Dialog.

Schuhmacher, S., Woerner, G. (1997). Encyklopedia mądrości Wschodu. Buddyzm. Hinduizm. Taoizm. Zen. Warszawa: Warszawski Dom Wydawniczy.

United Nations (2009). World Population Prospects: The 2008 Revision, Highlights. Departament of Economic and Social Affairs, Population Division. Working Paper No. ESA/P/WP.210. Pobrane z: http://www.un.org/esa/population/publications/wpp2008/ wpp2008_highlights.pdf.

Westley, S., Mason, A. (2002). Asia’s Aging Population. The Future of Population in Asia. Research Program, Population and Health Studies. Honolulu: East-West Center.

Wang, Hongyi. (2013). Postnatal care centers' popularity booms. China Daily, February 26. Pobrane z: http://www.chinadaily.com.cn/china/2013-02/26/content_16258718.htm. 